\title{
KORELASI CAMPURAN STARTER LACTOBACILLUS PLANTARUM DENGAN STREPTOCOCCUS THERMOPHILLUS TERHADAP KARAKTERISTIK MINUMAN SINBIOTIK UBI JALAR (Ipomoea batatas L.) KUNING
}

\author{
Wisnu Cahyadi \\ Hervelly \\ Tria Okta Wulandari \\ Program Studi Teknologi Pangan, Fakultas Teknin, Universitas Pasundan, J1. Dr. Setiabudhi no 93, Bandung, 40153, \\ Indonesia. \\ Email: wisnucahyadi@unpas.ac.id
}

\begin{abstract}
Abstrak
Penelitian ini bertujuan untuk melihat korelasi campuran starter Lactobacillus plantarum dan Streptococcus thermophillus terhadap karakteristik minuman sinbiotik ubi jalar kuning. Metode penelitian dilakukan dalam dua tahap, yaitu penelitian pendahuluan dan utama. Penelitian pendahuluan yang dilakukan yaitu inokulasi bakteri, pembuatan starter, pembuatan sari ubi jalar, dan penentuan jumlah sel, penelitian utama yaitu melihat korelasi antara campuran starter yang digunakan terhadap respon yang dilakukan yaitu respon organoleptik, kimia, dan respon mikrobiologi. Berdasarkan hasil penelitian didapatkan hasil uji organoleptik pada atribut rasa, aroma dan tekstur memiliki korelasi terhadap campuran starter, pada analisis mikrobiologi hitung jumlah sel menggunakan metode TPC pada bakteri Lactobacillus plantarum yaitu $2.39 \times 10^{7}$ pada bakteri Streptococcus thermophillus yaitu $2.53 \times 10^{7}$, pada respon kimia di dapatkan hasil \% serat, pH, Viskositas, asam laktat dan aktivitas antioksidan memiliki korelasi terhadap campuran starter.
\end{abstract}

\begin{abstract}
This study aims to look at the correlation of the mixture of starter Lactobacillus plantarum and Streptococcus thermophillus to the characteristics of the yellow sweet potato synbiotic drink. The research method is carried out in two stages, namely preliminary and primary research. Preliminary research was carried out namely bacterial inoculation, making starters, making sweet potato juice, and determining cell counts, the main research was looking at the correlation between the starter mixtures used in response to organoleptic, chemical, and microbiological responses. Based on the results of the study, the results of organoleptic tests on taste, aroma and texture attributes correlated with the starter mixture, in the microbiological analysis of cell counts using the TPC method on Lactobacillus plantarum ie $2.39 \times 107$ in Streptococcus thermophillus, $2.53 \times 107$, in the chemical response in get the results of $\%$ fiber, $\mathrm{pH}$, viscosity, lactic acid and antioxidant activity have a correlation with the starter mixture.
\end{abstract}




\section{Pendahuluan}

Sinbiotik merupakan potensi yang sinergi antara probiotik dan prebiotik berada didalam suatu makanan atau minuman. Probiotik merupakan mikroorganisme non patogen yang hidup sebagai mikroflora pencernaan atau usus yang dapat memberikan pengaruh positif dgan manfaat terhadap kesehatan, sedangkan prebiotik merupakan substrat atau bahan makanan bagi bakteri probiotik dimana substrat ini akan membantu pertumbuhan bakteri probiotik yang berada dalam satu kolon sehingga diperoleh kondisi fisiologis dan metabolik yang dapat memberikan perlindungan pada kesehatan saluran pencernaan dan usus (Hui, 2012).

Menurut Surono (2004), bahwa dalam fermentasi susu ada beberapa zat gizi yang mengalami perubahan kandungannya, salah satunya adalah protein. Protein yang terkandung di dalam susu akan dirombak oleh bakteri asam laktat dan menghasilkan asam amino bebas. Asam amino ini akan digunakan oleh bakteri untuk mensintesis selnya.

Pembuatan minuman sinbiotik mengandung bakteri asam laktat yaitu Lactobacillus plantarum dan Streptococcus thermophilus. Streptococcus thermophilus dan Lactobacillus plantarum diharapkan dapat menghasilkan tekstur, aroma, dan rasa paling baik. Penggunakan bakteri Lactobacillus plantarum karena dapat menghasilkan asam laktat yang cukup tinggi sehingga efektif untuk menghambat mikroorganisme pathogen serta bersifat toleran terhadap garam, memproduksi asam dengan cepat dan memiliki ph ultimat, (Buckle et al., 1987). Sedangkan penggunaan bakteri Streptococcus thermophilus karena bakteri tersebut dapat menghasilkan tektur dan cita rasa pada minuman sinbiotik tersebut.

Ubi jalar digunakan sebagai bahan untuk fermentasi minuman sinbotik ini karena ubi jalar memiliki nutrisi yang sangat baik untuk tubuh, seperti antioksidan, serat, karbohidrat dan lain nya. Karbohidrat yang terkandung dalam ubi jalar tidak dapat dicerna dan diserap biasannya dalam bentuk oligosakarida dan serat pangan oleh sebab itu dapat dimanfaatkan sebagai minuman sinbiotik ( Cahyono, 2000).

Collin (1999) dalam sudarmo et al.(2009) bahwa keuntungan dari kombinasi prebiotik dan probiotik dalam bahan pangan adalah meningkatkan daya tahan hidup bakteri probiotik oleh karena itu substrat yang spesifik telah tersedia untuk fermentasi sehingga tubuh mendapat manfaat yang lebih sempurna dari kombinasi ini.

\section{Metode Penelitian}

Bahan-bahan yang digunakan dalam penelitian pembuatan minuman sinbiotik ubi jalar kuning yang berumur 16 minggu atau berkisaran 3,5 bulan setelah tanam yang diperoleh dari perkebunan ubi jalar, almunium foil, kertas saring, susu, sukrosa, skim milk, starter Lactobacullus plantarum dan Streptococcus thermophilus.

Bahan-bahan yang digunakan dalam analisis meliputi aquadest, indikator phenolphthalein, $\mathrm{NaOH}$ $1,1 \mathrm{~N}, \mathrm{HCL}$ pekat, amylum, $\mathrm{I}_{2} 0,01 \mathrm{~N}, \mathrm{H}_{2} \mathrm{SO}_{4} 6 \mathrm{~N}, \mathrm{KI}$, $\mathrm{Na}_{2} \mathrm{~S}_{2} \mathrm{O}_{2} 1 \mathrm{~N}, \mathrm{HCL} 9,5 \mathrm{~N}, \mathrm{NaOH} 30 \%$, MRS, MSA, NHeksan, dan air streril.

Alat yang digunakan dalam pembuatan minuman sinbiotik adalah timbangan, panci, kompor, inkubator, sendok, thermometer, jar kaca, labu erlemeyer $250 \mathrm{ml}$ dan corong. Alat yang digunakan untuk analisis kimia yaitu labu erlemeyer $100 \mathrm{ml}$, gelas ukur, batang pengaduk, pipet volumetri, pipet tetes, neraca digital, biuret, gelas kimia, corong, labu takar, kompor, Bunsen, statif, klem, penangas, viskometer, pikno meter, refluks, dan $\mathrm{pH}$ meter.

Metode penelitian dilakukan dalam dua tahap, yaitu penelitian pendahuluan dan utama. Penelitian pendahuluan yang dilakukan yaitu inokulasi bakteri, pembuatan starter, pembuatan sari ubi jalar kuning, dan penentuan jumlah sel menggunakan metode TPC (total plate count), penelitian utama yaitu melihat korelasi antara campuran starter yang digunakan terhadap respon yang dilakukan yaitu respon organoleptik, respon kimia, dan respon mikrobiologi.

Rancangan respon yang digunakan untuk penelitian ini adalah respon organoleptik, fisik, kimia dan mikrobiologi. Respon fisik yang dilakukan adalah penentuan viskositas menggunakan viskometer, respon kimia yang dilakukan adalah analisis \% serat menggunakan metode gravimetri, Total asam menggunakan metode titrasi asam basa, $\mathrm{pH}$ menggunakan $\mathrm{pH}$ meter dan antioksidan, dan respon mikrobiologi. Penelitian utama yang dilakukan meliputi analisis total asam, analisis \% serat, $\mathrm{pH}$, dan antioksidan. menghitung jumlah sel menggunakan TPC (total plate count).

\section{Hasil dan Pembahasan \\ Hasil Penelitian Pendahuluan}

Penelitian pendahuluan yaitu menghitung jumlah sel menggunakan metode TPC (total plate count), hasil dapat dilihat pada tabel 1.

Tabel 1. Hasil perhitungan jumlah sel dengan menggunakan metode TPC

\begin{tabular}{|c|c|c|}
\hline Bakteri & Media & Cfu/ml \\
\hline $\begin{array}{c}\text { Lactobacillus } \\
\text { plantarum }\end{array}$ & MRS & $2,39 \times 10^{7}$ \\
\hline $\begin{array}{c}\text { Streptococcus } \\
\text { thermophillus }\end{array}$ & MSA & $2,53 \times 10^{7}$ \\
\hline
\end{tabular}

Berdasarkan hasil perhitungan jumlah sel hidup dengan menggunkan metode TPC (Total Plate count) jumlah mikroba pada bakteri Lactobacillus plantarum yaitu sebesar 2,39 × $10^{7}$ dan Streptococcus thermophillus yaitu sebesar $2,53 \times 10^{7}$ dimana hasil tersebut sesuai 
dengan syarat standar SNI th 2009, dimana jumlah minimum koloni/ml yaitu $1 \times 10^{6}$. Jika hasil yang di peroleh masih di bawah standar kemungkinan di sebabkan beberapa faktor seperti kurang nya masa inkubasi dari bakteri dan bakteri yang digunakan sudah terlalu lama.

\section{Hasil Penelitian Utama \\ 1. Viskositas}

Tabel 2. Viskositas pada minuman sinbiotik ubi jalar kuning dengan berbagai konsentrasi campuran starter

\begin{tabular}{|c|c|}
\hline Konsentrasi Bakteri (\%) & Viskositas (mPa.s) \\
\hline 2 & 60 \\
\hline 4 & 83 \\
\hline 6 & 110 \\
\hline 8 & 115 \\
\hline
\end{tabular}

Berdasarkan dari data tabel 2 menunjukkan campuran starter Lactobacillus plantarum dan Streptococcus thermophillus dimana semakin tinggi konsentrasi starter maka viskositas semakin meningkat, hal ini diduga disebabkan oleh mikroba dalam starter yang mempunyai kemapuan mendenaturasi protein dalam lemak susu sehingga menyebakan koagulasi dan menyebabkan tekstur susu menjadi kental.

Hal ini menunjukkan bahwa protein akan mengalami denaturasi dalam kondisi asam yang dihasilkan oleh mikroba penghasil asam serta $\mathrm{pH}$ yang rendah. Harjiyanti (2013), dalam penelitiannya menyebutkan bahwa terbentuknya asam laktat oleh bakteri asam laktat menyebabkan peningkatan total asam sehingga kasein mengalami koagulasi dengan pembentukan gel.

2. $\mathrm{pH}$

Tabel 3. pH pada minuman sinbiotik ubi jalar kuning dengan berbagai konsentrasi campuran starter Lactobacillus plantarum dan Streptoccocu thermophillus

\begin{tabular}{|c|c|}
\hline Konsentrasi Starter (\%) & $\mathrm{pH}$ \\
\hline 2 & 5,10 \\
\hline 4 & 4,98 \\
\hline 6 & 4,70 \\
\hline 8 & 4,23 \\
\hline
\end{tabular}

Berdasarkan data tabel 3 menunjukkan campuran starter Lactobacillus plantarum dan Streptococcus thermophillus dimana semakin tinggi campuran starter didapatkan $\mathrm{pH}$ yang semakin asam ataupun semakin rendah. Lengky et al. (2013) dalam penelitiannya menyebutkan bahwa $\mathrm{pH}$ akan lebih rendah ketika persentasi starter yang digunakan semakin tinggi. Ketika konsentrasi starter lebih tinggi maka tingkat keasaman akan semakin tinggi. Nilai $\mathrm{pH}$ atau derajat keasaman diperoleh dengan pengukuran secara langsung menggunakan $\mathrm{pH}$ meter. Lengkey et al. (2013) menambahkan bahwa nilai $\mathrm{pH}$ dapat diperoleh karena terdapat kandungan asam oleh bakteri starter dalam sampel. Nilai $\mathrm{pH}$ lebih asam (rendah) dengan konsentrasi starter yang lebih tinggi.

Haryadi dkk. (2013) menyebutkan bahwa penurunan $\mathrm{pH}$ menyebabkan rasa menjadi lebih asam karena pembentukan asam laktat sebagai produk utama hasil metabolisme bakteri asam laktat.

\section{Kadar Total Asam}

Tabel 4. Total Asam pada minuman sinbiotik ubi jalar kuning dengan berbagai konsentrasi campuran starter Lactobacillus plantarum dan Streptoccocu thermophillus .

\begin{tabular}{|c|c|}
\hline Konsentrasi Bakteri (\%) & Asam Laktat (\%) \\
\hline 2 & 0,41 \\
\hline 4 & 0,47 \\
\hline 6 & 0,59 \\
\hline 8 & 0,68 \\
\hline
\end{tabular}

Dari data Tabel 4. menunjukkan campuran starter Lactobacillus plantarum dan Streptococcus thermophillus menunjukkan bahwa semakin banyak konsentrasi bakteri maka persen asam laktat juga semakin tinggi namun masih sesuai dengan standar (SNI) minuman fermentasi berperisa th 2009 yaitu 0,20,9\%. Harjiyanti (2013), menyebutkan bahwa waktu inkubasi dan konsentrasi starter dapat berpengaruh terhadap pembentukan asam laktat. Waktu inkubasi yang terlalu pendek menyebabkan laktosa dalam susu belum termanfaatkan secara maksimal oleh BAL yang memfermentasi laktosa menjadi asam laktat. Mal dkk (2013) menambahkan bahwa keasaman yang di ekspresikan sebagai kadar asam laktat pada yoghurt tergantung pada laktosa yang difermentasi oleh bakteri asam laktat.

\section{Kadar Serat}

Tabel 5. kadar serat pada minuman sinbiotik ubi jalar kuning dengan berbagai konsentrasi campuran starter Lactobacillus plantarum dan Streptoccocu thermophillus

\begin{tabular}{|c|c|}
\hline Konsentrasi Starter (\%) & Serat (\%) \\
\hline 2 & 2,8 \\
\hline 4 & 2,6 \\
\hline 6 & 2 \\
\hline 8 & 1,3 \\
\hline
\end{tabular}

Dari data tabel 5 menunjukkan campuran starter Lactobacillus plantarum dan Streptococcus 
thermophillus banyaknya campuran starter yang di tambahkan maka memperlihatkan semakin rendahnya kadar serat yang terkandung pada minuman sinbiotik ubi jalar ini. Penurunan kadar serat pada semakin tingginya starter yang digunakan pada pembuatan minuman sinbiotik ini adalah semakin banyakknya jumlah starter yang di tambahkan maka semakin banyak pula bakteri yang membutuhkan nutrisi untuk pertumbuhannya, oleh sebab itu terjadilah penurunan serat pada semakin tinggi konsentrasi starter. Serat mempunyai peranan penting dalam proses pencernaan makanan dalam tubuh, karena serat merupakan suatu karbohidrat komplek di dalam bahan pangan yang tidak dapat di cerna oleh enzim-enzim pencernaan, sehingga dapat mencapai usus besar dan di cerna oleh bakteri probiotik. Novelina (2013).

\section{Aktivitas Antioksidan}

Tabel 6. Aktivitas antioksidan pada minuman sinbiotik ubi jalar kuning dengan berbagai konsentrasi campuran starter Lactobacillus plantarum dan Streptoccocu thermophillus

\begin{tabular}{|c|c|}
\hline Campuran Starter (\%) & konsentrasi $(\mathrm{ppm})$ \\
\hline 2 & 8460,46 \\
\hline 4 & 8205,36 \\
\hline 6 & 7907,95 \\
\hline 8 & 7673,62 \\
\hline
\end{tabular}

Dari data tabel 6 menunjukkan campuran starter Lactobacillus plantarum dan Streptococcus thermophillus memperlihatkan semakin banyaknya campuran starter yang di tambahkan maka memperlihatkan semakin rendahnya konsentrasi ppm dan semakin kuat dalam menangkal radikal bebas.

Peningkatan konsentrasi aktivitas antioksidan selama fermentasi berlangsung terjadi seiring dengan pertumbuhan bakteri asam laktat. Artinya, peningkatan populasi bakteri akan diikuti oleh peningkatan aktivitas antioksidan. Dimana semakin tinggi nilai konsentrasi ppm pada sampel untuk mengangkal radikal bebas DPPH radikal bebas semakin lemah, nilai IC50 (Inhibition Concetration 50) adalah konsentrasi yang menyebabkan hilangnya $50 \%$ aktivitas DPPH atau konsentrasi antioksidan yang mampu meredam radikal bebas sebanyak 50\% dibanding kontrol melalui suatu persamaan garis linier. ( Molyneux, 2004).

\section{Atribut rasa}

Tabel 7. Tingkat kesukaan konsumen pada atribut rasa

\begin{tabular}{|c|c|}
\hline Konsentrasi (\%) & Tingkat Kesukaan \\
\hline 2 & 3,7 \\
\hline 4 & 3,7 \\
\hline 6 & 3,85 \\
\hline 8 & 4,5 \\
\hline
\end{tabular}

Pada Tabel 8 terlihat bahwa berdasarkan hasil yang didapatkan memperlihatkan adanya korelasi konsentrasi bakteri lactobacillus Plantarum dan Streptococcus thermophillus terhadap atribut aroma yang di hasilkan pada minuman sinbiotik ubi jalar kuning, dimana semakin besar konsentrasi starter Lactobacillus plantarum dan Streptecoccus thermophillus maka konsumen semakin menyukai aroma khas asam yang dihasilkan.

\section{Tekstur}

Tabel 9. Tingkat kesukaan konsumen pada tekstur.

\begin{tabular}{|c|c|}
\hline Konsentrasi (\%) & Tingkat Kesukaan \\
\hline 2 & 3,65 \\
\hline 4 & 3,7 \\
\hline 6 & 3,7 \\
\hline 8 & 4,5 \\
\hline
\end{tabular}

Pada tabel 9 terlihat bahwa berdasarkan hasil yang didapatkan memperlihatkan adanya korelasi konsentrasi bakteri Lactobacillus plantarum dan Streptococcus thermophillus terhadap atribut tekstur. yang di hasilkan pada minuman sinbiotik ubi jalar kuning, dimana semakin besar konsentrasi starter Lactobacillus plantarum dan Streptecoccus thermophillus maka konsumen semakin menyukai viskositas yang lebih kental.

\section{Kesimpulan}

Berdasarkan hasil penelitian ini terdapat korelasi campuran starter Lactobacillus Plantarum dengan Streptococcus thermophillus terdapat karateristik minuman sinbiotik ubi jalar kuning.

Berdasarkan hasil penelitian di dapatkan korelasi terhadap viskositas dengan koefisien $\mathrm{r}$ yaitu 0,9702 , terhadap $\mathrm{pH}$ diperoleh koefisien $\mathrm{r}$ yaitu 0,961 , terhadap asam laktat/total asam di dapatkan koefisien $r$ yaitu 0,9927 , terdapat \% serat di dapatkan korelasi koefisien $\mathrm{r}$ yaitu -0,9751, terhadap aktivitas antioksidan diperoleh koefisien korelasi r yaitu - 0,990

Berdasarkan hasil uji organoleptik didapat bahwa penilaian yang di berikan panelis terhadap campuran starter Lactobacillus Plantarum dan Streptococcus Thermophillus pada atribut rasa dengan 
konsentrasi yang berbeda memiliki korelasi positif dengan nilai koefisien korelasi $\mathrm{r}$ sebesar 0,9158, pada atribut aroma dengan konsentrasi yang berbeda memiliki korelasi positif dengan nilai koefisien korelasi $r$ sebesar 0,8626, dan pada tekstur yang berbeda memiliki korelasi positif dengan nilai koefisien korelasi r sebesar 0,8048 dimana pada atribut rasa, aroma dan viskositas memiliki korelasi sangat kuat.

\section{Daftar Pustaka}

1. Buckle, K. A., Edwards, R. A., Fleet, G. H. dan Wotton, M. 1987. Ilmu Pangan. UI Press, Jakarta.

2. Harjiyanti, Y. B. Pramono, S.Mulyani. 2013. Total Asam, Viskositas, Dan Kesukaan Pada Yoghurt Drink Dengan Sari Buah Mangga (Mangifera indica) Sebagai Perisa Alami. Jurnal Aplikasi Teknologi Pangan.

3. Lengkey, Hendronoto A.W., Siwi, Jan Alex, Balia, Roostita L. 2013. The Effect of Various Starter Dosages on Kefir Quality. Lucrări Ştiinţifice-Seria Zootehnie.

4. Mal, Rup, Radiati, Lilik Eka Dan Purwadi. 2013.

Pengaruh Lama Penyimpanan Pada Suhu Refrigerator Terhadap Nilai pH, Viskositas, Total Asam Laktat dan Profil Protein Terlarut Kefir Susu Kambing. Jurusan Teknologi Hasil Ternak, Fakultas Peternakan, Universitas Brawijaya, Malang.

5. SNI 2981:2009. Minuman Susu Fermentasi Berperisa. Badan Standarisasi Nasional.

6. Soemartono. 1984. Ubi Jalar . Penerbit CV. Yasaguna, Jakarta.

7. Sudono, Adi dan Usmiati, Sri. 2004. Pengaruh Starter Kombinasi Bakteri dan Khamir Terhadap Sifat Fisikokimia dan Sensori Kefir. Jurnal Pascapanen.

8. Susilorini, T. E. dan Sawitri, M. E. 2007. Produk Olahan Susu. Jakarta : Penebar Swadaya

9. Suhartini. 2009. Kajian Kearifan Lokal Masyarakat Dalam Pengelolaan Sumberdaya Alam Dan Lingkungan. Prosiding Seminar Nasional Penelitian, Pendidikan dan Penerapan MIPA. Jurusan Pedidikan Biologi FMIPA Universitas Negeri Yogyakarta. Yogyakarta.

10. Surono, I. S. 2004. Probiotik, Susu Fermentasi dan Kesehatan. Yayasan Pengusaha Makanan dan Minuman Seluruh Indonesia. Jakarta.Tensiska 2008. Serat Makanan.http://pustaka.unpad.ac.id. [diakses : 03 Oktober 2018].

11. Usmiati, S dan A. Priyanti. 2008. Penentuan lama sentrifuge minyak pada daging sapi. Mataram: Makalah Penunjang Seminar Nasional. Fakultas Pertanian Universitas Mataram.

12. Utama, C. S., B. Sulistiyanto, N. Suthama and B. E. Setiani. 2013. Utility of Rice Bran Mixed with Fermentation Extract of Vegetable Waste
Unconditioned as Probiotics from Vegetable Market. Internat. J. of Sci. and Eng.,

13. Volk dan Wheeler. 1993. Mikrobiologi Dasar I. Jakarta : Erlangga

14. Wageha, A. Khaled, G. and Joseg. B. 2008. Intenstinal Structure and Function of Broiler Chicken on Diets Supplementd with A Synbiotic Containing Enteroccus faecium and Oligosaccarides. Int J Mol, Sci. 9.

15. Waspodo, J.S. 2001. Efek Probiotik, Prebiotik, dan Sinbiotik bagi Kesehatan www.kompas.com/prebiotik. Diakses pada 20 april 2018.

16. Winarno, F.G., (1989), Kimia Pangan dan Gizi, Penerbit. PT. Gramedia Pustaka Utama, Jakarta.

17. Winarti, Sri. 2010. Makanan Fungsional. Graha Ilmu : Surabaya.

18. Yang, Z. 2000. Antimicrobial Compounds, and Extracellular Polysaccharides Produced by Lactic Acid Bacteria Structures and Properties. Dissertation, University of Helsinki, Faculty of Agriculture and Forestry. Helsinki.

19.Zakaria. 2003. Analisis Kandungan Mineral Magnetik pada Batuan Beku dari Daerah Istimewe Yogyakarta dengan Metode X-Ray Diffraction. Universitas Haluoleo: Fakultas Keguruan dan Ilmu Pendidikan. 